\title{
A DINÂMICA DO TRABALHO DE BRASILEIRAS EM LONDRES E O EMPIRISMO METODOLÓGICO
}

\author{
Ana Paula Archanjo Batarce ${ }^{1}$
}

\begin{abstract}
RESUMO
O presente artigo apresenta e discute os dados de uma pesquisa quantitativa realizada com mulheres brasileiras trabalhadoras e residentes na cidade de Londres. Para a coleta de dados foram aplicados 214 questionários, em 2014. Os dados delineiam o perfil laboral e o modo como as entrevistadas se inseriram e participaram do mercado de trabalho. Analisar migrações internacionais contemporâneas propõe desafios teóricos e metodológicos de investigação, uma vez que estas constituem fenômeno que está em constante movimento. Desta forma, paralelamente à apresentação dos dados, o artigo propõe uma discussão do percurso metodológico utilizado. A pesquisa evidenciou que a mobilidade laboral entre as mulheres migrantes não foi intensa em um espaço considerado de forte imigração.
\end{abstract}

Palavras - chave. Migração internacional. Mulheres brasileiras. Trabalhadoras. Pesquisa empírica. Londres.

\section{THE DYNAMICS OF THE WORK OF BRAZILIANS IN LONDON AND METHODOLOGICAL EMPIRISM}

\begin{abstract}
This article presents and discusses the data of a quantitative survey carried out with working Brazilian women living in the city of London. To collect data, 214 questionnaires were applied in 2014. The data outline the labor profile and the way the interviewees entered and participated in the labor market. Analyzing contemporary international migrations proposes theoretical methodological challenges of research, since these constitute a phenomenon that is in constant movement. Thus, in parallel to the presentation and discussion of the data, the article proposes a discussion of the methodology used.
\end{abstract}

\footnotetext{
${ }^{1}$ Doutora em Geografia pelo programa de Pós-graduação em Geografia da Universidade Estadual Paulista UNESP - Rio Claro - SP. Diretora da Associação dos Geógrafos Brasileiros - AGB - Seção Dourados. E-mail: aparchanjo@gmail.com

Esse artigo resulta de parte da tese intitulada: Imigração brasileira para o Reino Unido: O trabalho das mulheres em Londres e os Processos de Identificação/Diferenciação. A pesquisa foi financiada pela Fundação de Amparo à Pesquisa do Estado de São Paulo - FAPESP.
}

Estudos Geográficos, Rio Claro, 15(1): 210-230, jan./jun. 2017 (ISSN 1678—698X)

http://www.periodicos.rc.biblioteca.unesp.br/index.php/estgeo 
The research showed that labor mobility among migrant women was not intense in a space considered to be of a strong immigration

Key words. International migration. Brazilian women. Workers. Empirical research. London.

\section{INTRODUÇÃO}

Segundo dados das Organizações das Nações Unidas - ONU (2015) existem, aproximadamente, 7,3 bilhões de pessoas no mundo. Desse total, 244 milhões representam migrantes internacionais, ou seja, cerca de $3 \%$ da população global. Dessa cifra, 20 milhões de pessoas são refugiadas, principalmente, de guerras civis e de condições de vulnerabilidade social, como a fome procurando, assim, os países europeus como porta de entrada para uma vida melhor.

A migração internacional passou a ser fenômeno relevante para as diferentes nações, visto que os sujeitos migrantes fazem parte integral das economias e sociedades em que se encontram e se tornam uma fração de pessoas no cotidiano desses diferentes lugares. Dessa forma, chama-se a atenção para a distribuição espacial desses sujeitos migrantes nesses lugares, pois ela ocorre de forma desigual. Na América do Norte, na Europa e na Oceania, os migrantes internacionais representam $10 \%$ da população, enquanto que na África, Ásia, América Latina e Caribe, menos de $2 \%$ são estrangeiros (ONU, 2016). Observa-se que não se migra para qualquer país, mas para países cujo desenvolvimento econômico sobressai de tal forma, que atrai a atenção dos sujeitos migrantes, conforme se evidencia no cartograma 1.

Cartograma 1 - Número de migrantes internacionais por áreas de origem e destino (Hemisfério Sul e Norte) - 1990-2015 (milhões)

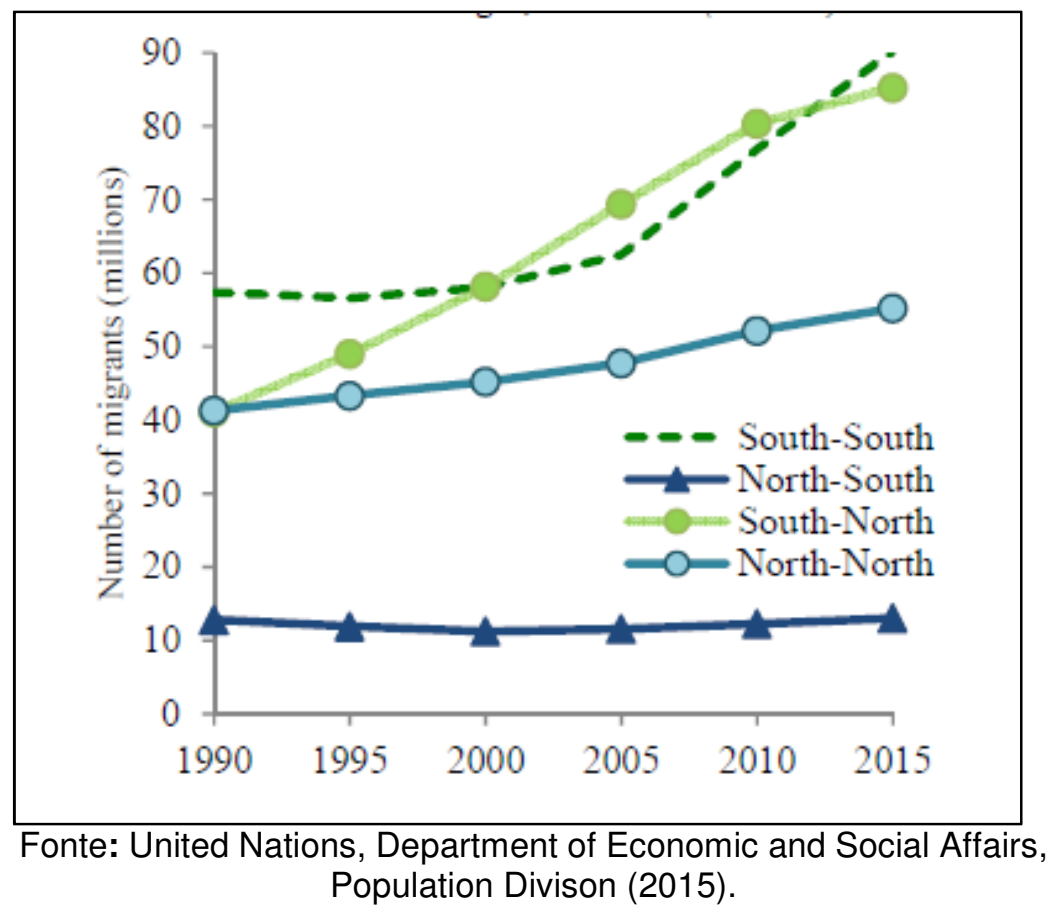

Estudos Geográficos, Rio Claro, 15(1): 210-230, jan./jun. 2017 (ISSN 1678—698X)

http://www.periodicos.rc.biblioteca.unesp.br/index.php/estgeo 
Nota-se que o direcionamento dos sujeitos migrantes é mais intenso no sentido Hemisfério Sul para o Hemisfério Norte, seguido da migração entre os países do Hemisfério Sul e a dos do Hemisfério Norte. Observa-se que a migração do Hemisfério Norte para o Hemisfério Sul acontece com menor intensidade.

Nesse contexto, o Brasil, segundo dados do Ministério das Relações Exteriores (2015), possui cerca de 3.083.255 de brasileiras e brasileiros espalhados pelo mundo, que migram principalmente para o Hemisfério Norte. Isso representa aproximadamente $1,5 \%$ do total da população brasileira, a qual se encontra na cifra de 207.652.000 de pessoas (Banco Mundial, 2015). No entanto, nem sempre foi assim, a intensificação do movimento migratório internacional de brasileiros para o mundo é um fenômeno recente.

O Brasil historicamente é reconhecido como um país receptor de migrantes, principalmente a partir do final do século XIX e início do século $X X$, com a chegada dos portugueses, italianos, espanhóis, japoneses, alemães, sírios libaneses, entre outros. Apenas a partir do final dos anos 1980 iniciou-se o processo inverso, acarretando "[...] uma mudança nos padrões migratórios. O Brasil passou de um país de imigração para um país de emigração" (VALENTINI, 2005, p. 10). Assim, a migração internacional de brasileiros para outros locais do mundo tornou-se um novo fenômeno populacional, caracterizado como:

[...] uma grande novidade para o seu corpo social que não havia sido registrada em nenhum outro momento anterior: o fenômeno da emigração brasileira. Pela primeira vez na história do Brasil, verificase um processo inédito de saída da população brasileira em direção a outros países do chamado Primeiro Mundo. Este processo, em grande parte, "assustou" a sociedade brasileira, porque, além de inédito, resultou num movimento emigratório que começou de forma sutil, e que foi aos poucos tomando amplas proporções em determinados setores mais ou menos específicos (Oliveira, 1997, p. $61)$.

Em pesquisas realizadas por Sales (1999, p. 17) encontraram-se, no "Caderno Especial da Folha de São Paulo, de 18-07-91", dados relativos ao crescimento desse fenômeno populacional indicando um valor aproximado de "1,25 milhão de brasileiros" que deixaram o país entre os anos de "1985 e 1987". Esses eram direcionados espacialmente: não se migrava para qualquer lugar, migrava-se para países como os "Estados Unidos (38\%), seguido do Paraguai (30\%), do Japão (13\%) e de vários países da Europa que, no conjunto, representavam cerca de 10\%" (Sales, 1999, p. 16).

Interessante destacar que os dados migratórios de fluxos apresentados pelo Ministério das Relações Exteriores do Brasil, em 2013, reafirmam o direcionamento espacial da migração apresentado por Sales, em 1999. Segundo estimativas populacionais de 2013 relativas às comunidades brasileiras no exterior, os Estados Unidos continuaram em primeiro lugar com 1007.000 de brasileiros; o Paraguai, continuou em segundo com 460.000; em terceiro, o Japão com 186.000 e a Europa, que conta com 737.000 brasileiros espalhados em seus países.

Embora os países europeus não sejam considerados os principais receptores de migrantes brasileiros, conforme os dados do Ministério das Relações Exterior

Estudos Geográficos, Rio Claro, 15(1): 210-230, jan./jun. 2017 (ISSN 1678—698X) 
brasileiro, desde o ano de 2008 até o ano de 2011 a Inglaterra se destacou por ser o principal país de destino dos brasileiros, no entanto, as pesquisas relacionadas a este fluxo migratório Brasil/Inglaterra ainda são incipientes.

Evidenciam-se, no Gráfico 1, os contingentes populacionais de brasileiras e brasileiros nos países que apresentam maiores estimativas populacionais na Europa, como Portugal, Espanha, Itália, Alemanha e Reino Unido, durante os anos de 2008 a $2014^{2}$. Os valores relacionados ao Reino Unido apresentaram as maiores estimativas até 2012, demonstrando justamente que este foi o principal destino de chegada de brasileiros e de brasileiras na Europa, especificamente na Inglaterra. Percebe-se que, do ano de 2012 a 2014, ocorreu pequena mudança no padrão, pois o contingente populacional de brasileiros(as) em Portugal e Espanha (timidamente) sobressai em relação ao do presente no Reino Unido.

Gráfico 1 - Estimativa da população brasileira (mil) na Europa nos países com maiores contingentes populacionais por ano (2008-2014)

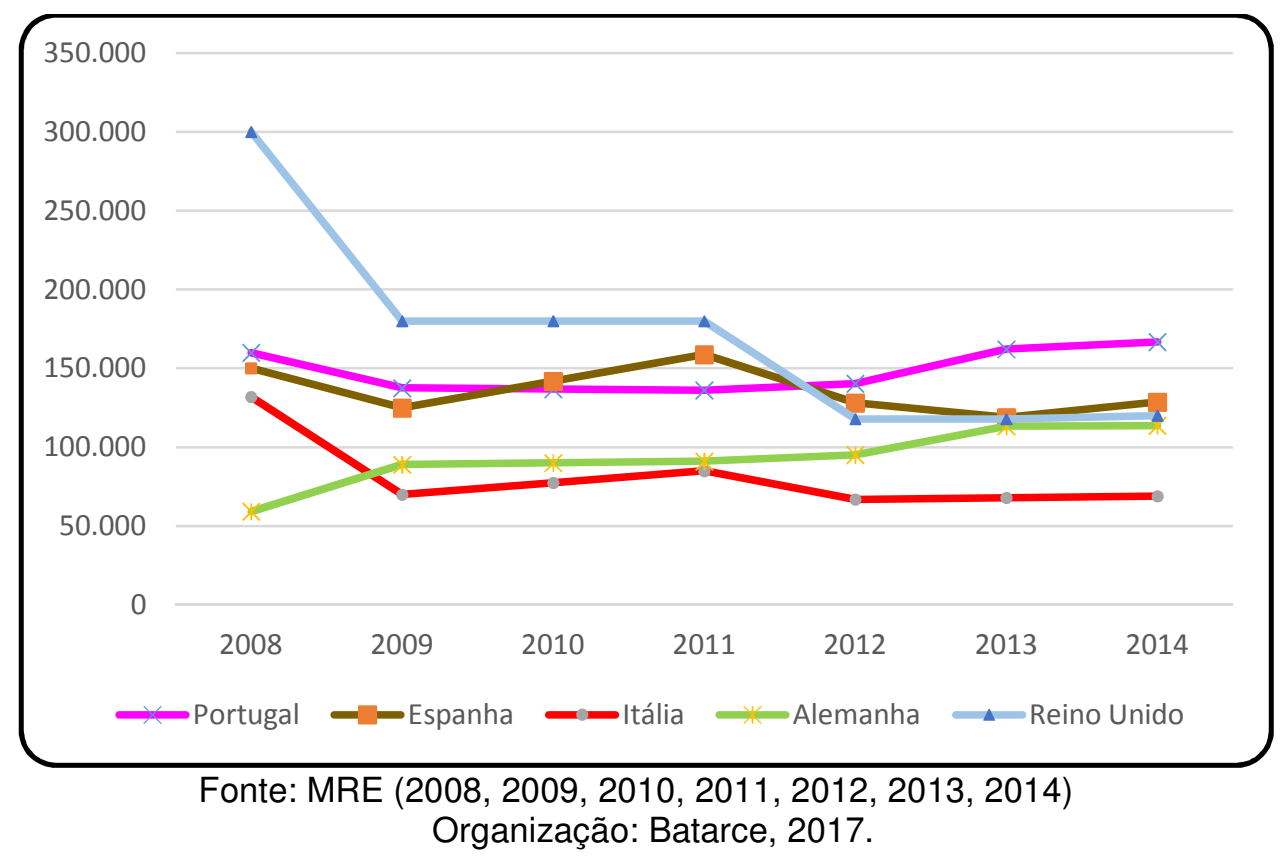

Objetiva-se, nesse sentido, demonstrar as formas de inserção e participação de mulheres brasileiras no mercado de trabalho londrino, com vistas a contribuir tanto para a construção do arcabouço teórico dos estudos migratórios a respeito da presença de trabalhadoras brasileiras em Londres, quanto para a compreensão da mobilidade do trabalho em espaços de forte imigração. Para tanto, faz-se necessário expressar o desenvolvimento da pesquisa empírica e sua importância na aquisição dos dados analisados.

\section{O EMPIRISMO METODOLÓGICO}

A fim de demonstrar as articulações entre os setores de atividade laboral e a mulher migrante trabalhadora brasileira em Londres, apresenta-se parte de pesquisa

\footnotetext{
${ }^{2}$ O gráfico baseia-se nas informações do Ministério das Relações Exteriores dos anos de 2008 a 2014, pois não existem dados disponíveis sobre o Reino Unido em relação aos anos de 2015 e 2016. Salienta-se que esses dados foram atualizados, pois se apresenta na tese a análise com recorte temporal de 2008-2012.

Estudos Geográficos, Rio Claro, 15(1): 210-230, jan./jun. 2017 (ISSN 1678-698X)

http://www.periodicos.rc.biblioteca.unesp.br/index.php/estgeo
} 
empírica realizada na capital inglesa no ano de 2014. Ressalta-se que as informações expostas nesse artigo resultam de estudo de doutorado em que foram utilizadas diferentes técnicas de coleta de dados. Desse modo, a pesquisa se estruturou em três etapas: a primeira, relacionada à aplicação dos questionários; a segunda, à realização das entrevistas; e a terceira que, efetuada ora concomitante ora não com as etapas anteriores, relaciona-se com as fontes iconográficas.

Isso posto, evidenciam-se, nesse artigo, informações referentes à aplicação dos questionários e aos resultados que contribuíram para se traçar o perfil laboral das mulheres brasileiras demonstrando a mobilidade do trabalho no período em que elas estiveram realizando alguma atividade econômica em Londres. Os dados apresentados resultam de um total de 214 questionários que foram aplicados a essas mulheres e apontam o tipo de trabalho que realizavam desde o momento de sua chegada àquele país até o ano de 2014.

Salienta-se que as perguntas utilizadas nos questionários foram elaboradas para serem funcionais, para que pudessem atingir o objetivo proposto e para serem inseridas no sistema estatístico online de coleta de dados quantitativos que foi utilizado, chamado Survey Monkey. Os questionários foram aplicados em diferentes etapas: de forma direta - face to face - e de forma indireta - on line -, via facebook e e-mail.

Antes do início da aplicação dos questionários foram realizados dois testes pilotos que auxiliaram na definição da área de estudos - os possíveis locais em que seria realizada a pesquisa e os prováveis sujeitos participantes. Destacamos dois momentos neste processo: em um primeiro momento, antes da realização dos testes piloto, estava definido que os questionários seriam aplicados a 35 mulheres trabalhadoras que deveriam desenvolver atividades em diferentes setores, por exemplo, no de negócios/serviços, no de comércio, de alimentos, de limpeza; ou às trabalhadoras autônomas. Participariam da pesquisa, inicialmente, 5 mulheres de cada setor da atividade econômica.

No segundo momento, marcado pela adaptação do questionário e pela realização do teste piloto, verificou-se dificuldade de encontrar mulheres dentro das categorias pré-estabelecidas e, neste sentido, adaptou-se novamente a amostragem diante de mais um desafio a ser transposto: Onde procurá-las? Como encontrá-las? Como encontrar especificamente trabalhadoras brasileiras que desenvolviam atividades no setor de negócios/serviços, no de alimentos, limpeza, comércio; e as autônomas? Qual seria a melhor forma de abordagem para poder aplicar os questionários?

Assim, traçaram-se quatro estratégias de procura: a primeira foi a de a pesquisadora estabelecer residência num local onde existia uma comunidade brasileira, isso ocorreu em Crystal Palace, situado no Sul de Londres e pertencente ao Borough Southwak. O estabelecimento de residência nesse lugar facilitou a aproximação com algumas pessoas fundamentais para a realização da pesquisa na região. Ressalta-se que essa área despertou a atenção porque nela existia uma igreja católica em que se realizava, aos domingos, missa em português por um padre brasileiro, fato que deixou clara a existência de uma comunidade brasileira no local.

A segunda estratégia foi a de conhecer os bairros de Willesden Junction e de Harlsden, localizados no distrito de Brent, porção noroeste da cidade e região destacada nos trabalhos de Evans devido à presença massiva de brasileiros. A primeira visita à área foi marcada pela observação, pelos registros fotográficos e pelo estabelecimento das primeiras conversas em alguns locais de comércio e de Estudos Geográficos, Rio Claro, 15(1): 210-230, jan./jun. 2017 (ISSN 1678-698X) http://www.periodicos.rc.biblioteca.unesp.br/index.php/estgeo 
serviços (salões de beleza, mercearias e restaurantes). Foi a primeira tentativa para abrir alguns canais de contato.

A visita a Brent foi responsável pela mudança em um dos aspectos da pesquisa empírica: efetuar pesquisa com mulheres brasileiras que trabalhavam nos setores de comércio, negócios, limpeza, alimentos, assim como com mulheres donas do próprio negócio (trabalhadoras autônomas). Percebeu-se que atender a essas categorias previamente estabelecidas seria difícil por dois motivos: o primeiro relacionava-se com o objetivo da pesquisa, que era o de compreender a mobilidade do trabalho feminino; assim, não seria possível fixar previamente os setores da atividade laboral. Optou-se, então, por aplicar o questionário a qualquer mulher trabalhadora, pois a mudança atenderia aos objetivos da pesquisa. $O$ segundo motivo relacionava-se à prática em campo, ou seja, à abordagem das pessoas. Observou-se que abordar as mulheres para a realização da pesquisa científica não seria fácil. Dessa forma, além de explicar-lhes a motivação da pesquisa e de convidá-las a participar, seria necessário, também, antes de iniciar a aplicação do questionário, perguntar-lhes se trabalhavam, que tipo de trabalho realizavam e há quanto tempo residiam em Londres. Na teoria, parecia funcional abordar uma pessoa com essas perguntas mas, a partir da observação das pessoas em Brent, percebeu-se que eram muitas as perguntas para uma primeira abordagem, portanto, seria necessário repensar a realização da abordagem em um lugar como Londres.

Londres é tida como uma cidade global, cosmopolita, as pessoas têm pressa para tudo: para chegar ao trabalho, para sair do trabalho, para chegar à casa, para sair de casa, para não perder o trem ou o ônibus ou o metrô.... Até para comer as pessoas não param, elas comem andando nas ruas, nos trens ou ônibus enquanto se locomovem de um lugar para o outro. A vida em Londres é rápida, sempre rápida, isto é uma característica local, pois observando-se o interior da Inglaterra, verifica-se que a vida tem um tempo mais lento.

Essa rapidez das pessoas e da cidade atinge os migrantes internacionais, atinge a mulher trabalhadora brasileira, e essa situação, que é constante, não foi funcional para a aplicação do questionário. Pelo menos no que se refere à abordagem em comércios, mercearias, cafés, em ruas onde se concentravam brasileiros e em estações de trem. Portanto, a observação nos bairros de Willesden Junction e de Harlsden foi fundamental para que se percebesse a necessidade de mudança relacionada à definição prévia dos setores laborais das mulheres que fariam parte da amostragem. A exigência então passou a ser a de a mulher estar trabalhando em qualquer setor e estar residindo em Londres há pelo menos um ano. Segundo as Nações Unidas (2002), para ser considerado migrante internacional a pessoa deve estar fora do país de origem há mais de ano. Com essa mudança estratégica foi possível traçar o perfil do tipo de trabalhadora brasileira e a mobilidade do trabalho em Londres.

A terceira estratégia se estabeleceu pelo início da utilização da técnica snow ball (bola de neve ou indicação de pessoas). Na tentativa de se criar uma rede de contatos, escolheram-se três pessoas "chaves", mas apenas uma delas indicou outra pessoa. Outro contato efetivou-se a partir da participação da pesquisadora no III Seminário de Estudos sobre Migração Brasileira na Europa, promovido pelo GEB, e esta pessoa também indicou outra pessoa. Essa tentativa de utilização do snow ball não funcionou, pois se esperava um maior número de contatos.

A quarta e última estratégia de procura por mulheres para a aplicação dos questionários foi a de estabelecer contatos com as organizações que atendiam especificamente à comunidade brasileira. Procurou-se três organizações não Estudos Geográficos, Rio Claro, 15(1): 210-230, jan./jun. 2017 (ISSN 1678-698X) http://www.periodicos.rc.biblioteca.unesp.br/index.php/estgeo 
governamentais: a Associação Brasileira no Reino Unido - ABRAS, a CASA DO BRASIL e a Latin American Women's Rights Service - LAWRS, e o Consulado brasileiro.

Para a realização das visitas às instituições, tornou-se necessário escrever uma carta formal, dando explicações sobre a pesquisa e solicitando autorização para a aplicação dos questionários. Além de apresentação de carta formal, participou-se, no Consulado Brasileiro e na LAWRS, de audiência para explanação da pesquisa proposta. Depois disso é que essas instituições autorizaram a realização da pesquisa.

A aplicação dos questionários ocorreu de duas formas diferentes: pessoalmente e no formato digital (online). A primeira delas - e o principal modo de aplicação utilizado na pesquisa, conhecido como face to face ou face a face caracteriza-se pelo formato em que o pesquisador(a) realiza diretamente a aplicação do questionário à pessoa que se disponibiliza a responder. As respostas foram sendo coletadas e transferidas do formato papel (questionários) para o sistema estatístico online Survey Monkey.

Sublinhe-se que o formato face to face ocorreu em três diferentes locais. $\mathrm{O}$ principal deles foi o Consulado brasileiro, que se localiza próximo à estação de Oxford Circus, zona 1, área central da cidade. Neste local realizou-se a aplicação dos questionários a mulheres que tinham horário agendado para atendimento. Observa-se, na fotografia 1, a fachada da entrada do Consulado.

\section{Fotografia 1 - Fachada do Consulado brasileiro em Londres}

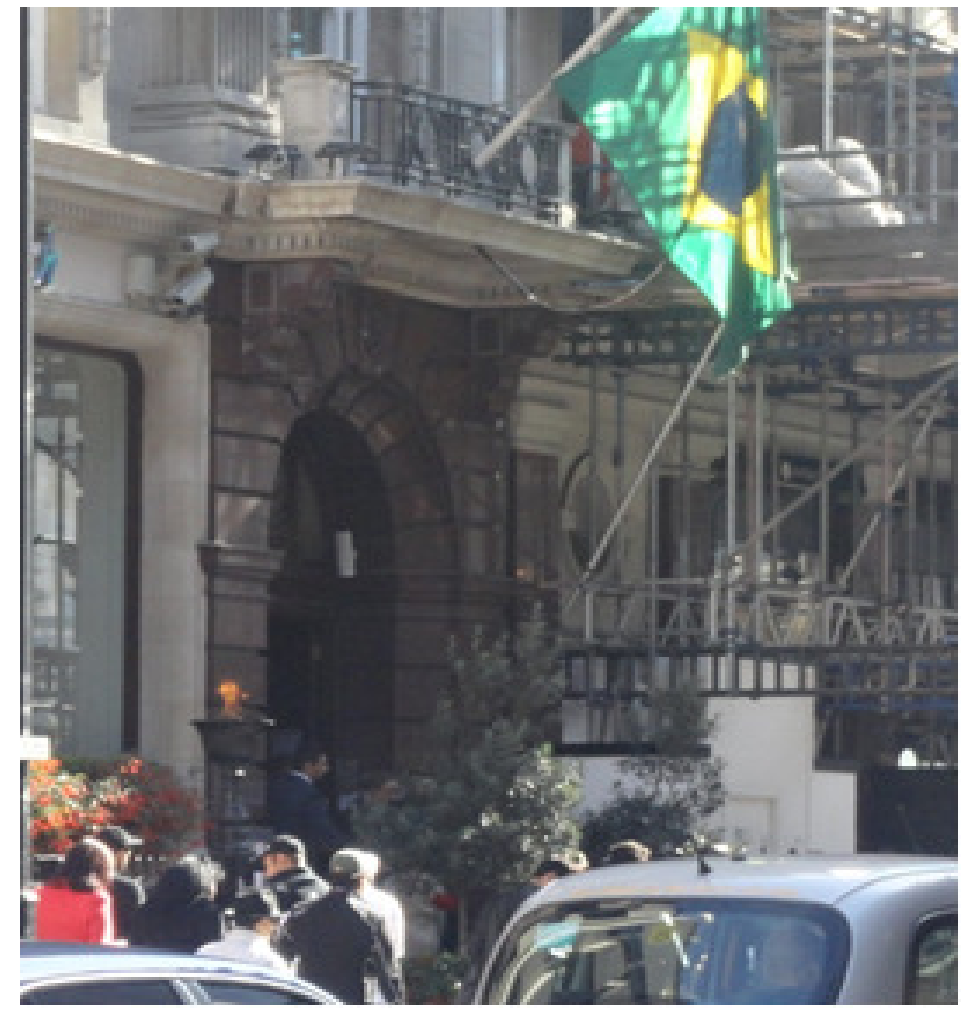

Fonte: BATARCE, A.P.A. 2014.

Destaca-se que foi feito um pedido formal à embaixadora Maria De Lujan Caputo Winkler, Consulesa-Geral do Brasil, para a realização do estudo no

Estudos Geográficos, Rio Claro, 15(1): 210-230, jan./jun. 2017 (ISSN 1678-698X) 
Consulado e que a permissão facilitou tanto o desenvolvimento da pesquisa como permitiu o estabelecimento de uma rede de contatos que proporcionou o desenrolar do snow ball.

Também no Consulado foi possível a aplicação dos questionários via endereço eletrônico de suas funcionárias. Nesse processo, percebeu-se que era necessário tempo para se construir uma rede de contatos, isto é, tempo para a pesquisa empírica iniciar e caminhar positivamente.

Ainda no Consulado, por meio da aplicação de um dos questionários, encontrou-se um contato chave que forneceu cerca de 10 indicações de mulheres brasileiras que eram trabalhadoras autônomas. Essa pessoa já estava em Londres há onze anos (2014) e prestava serviços à comunidade brasileira, por isso conhecia muitas pessoas, muitas mulheres. Assim, foram surgindo indicações individuais de outras pessoas e ampliou-se a rede de contatos, o que possibilitou que se atingisse um universo significativo de trabalhadoras e que houvesse a movimentação da técnica de pesquisa snow ball.

O outro local de aplicação face to face ocorreu em Trafalgar Square, um dos famosos pontos turísticos de Londres, visitado por milhares de pessoas anualmente, local em que se encontra a National Gallery, Galeria Nacional de exposição de artes. Trata-se de uma praça que se encontra na zona 1, área central da cidade. No dia 12/06/2014, início da Copa do Mundo no Brasil, ocorreu neste local a festa brasileira promovida pela embaixada brasileira. O evento, chamado de Brazil Day (Dia do Brasil) (como pode ser observado nas fotografias 2 e 3 respectivamente: Brazil Day - Trafalgar Square e Brazil Day - Trafalgar Square (visão ampliada). Essa festa faz parte das programações anuais realizadas pela Embaixada. Neste dia foram aplicados 15 questionários.

\section{Fotografia 2 - Brazil Day - Trafalgar Square}

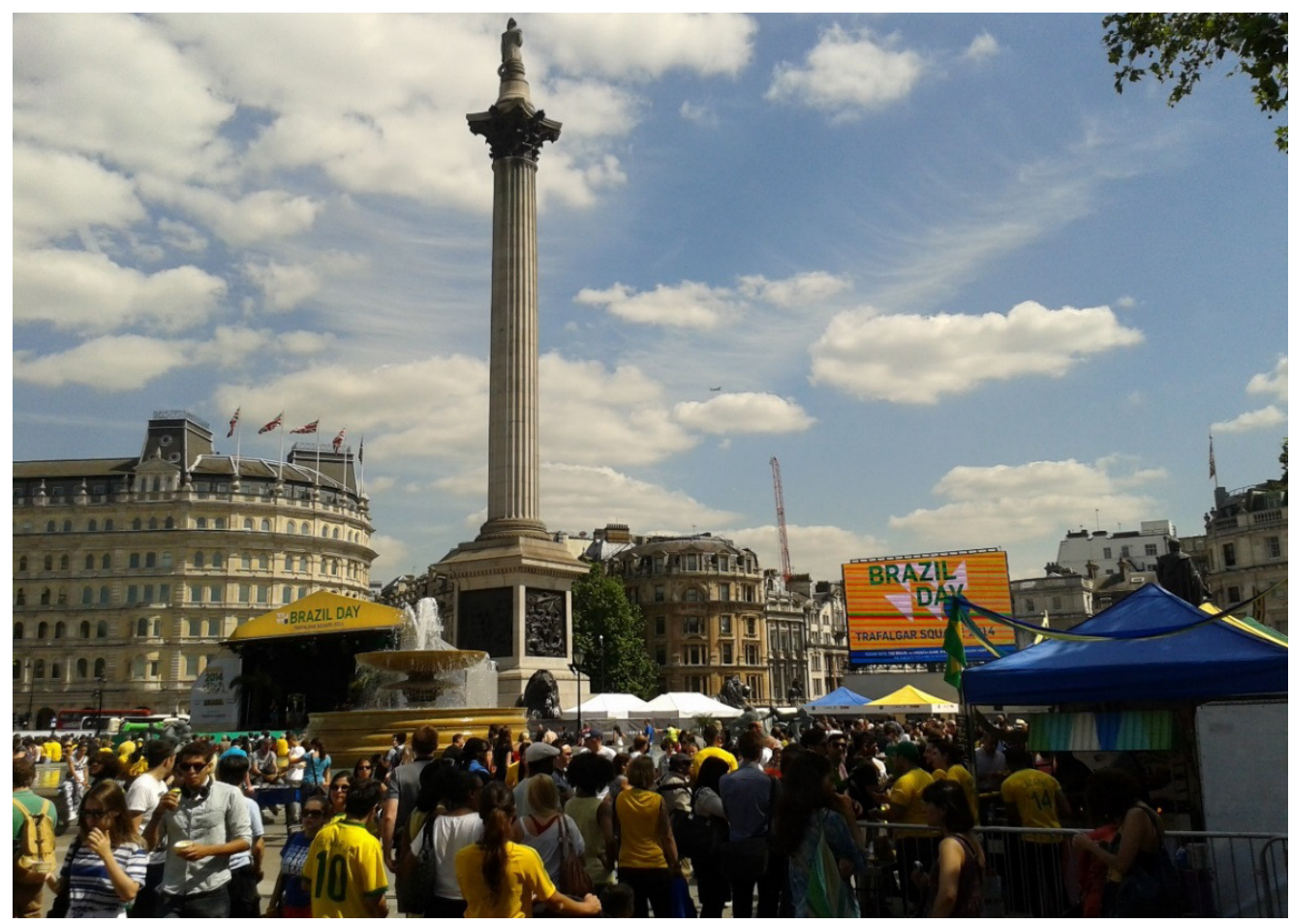

Fonte: BATARCE, A.P.A. 2014.

Estudos Geográficos, Rio Claro, 15(1): 210-230, jan./jun. 2017 (ISSN 1678-698X) http://www.periodicos.rc.biblioteca.unesp.br/index.php/estgeo 
Fotografia 3 - Brazil Day - Trafalgar Square (visão ampliada)

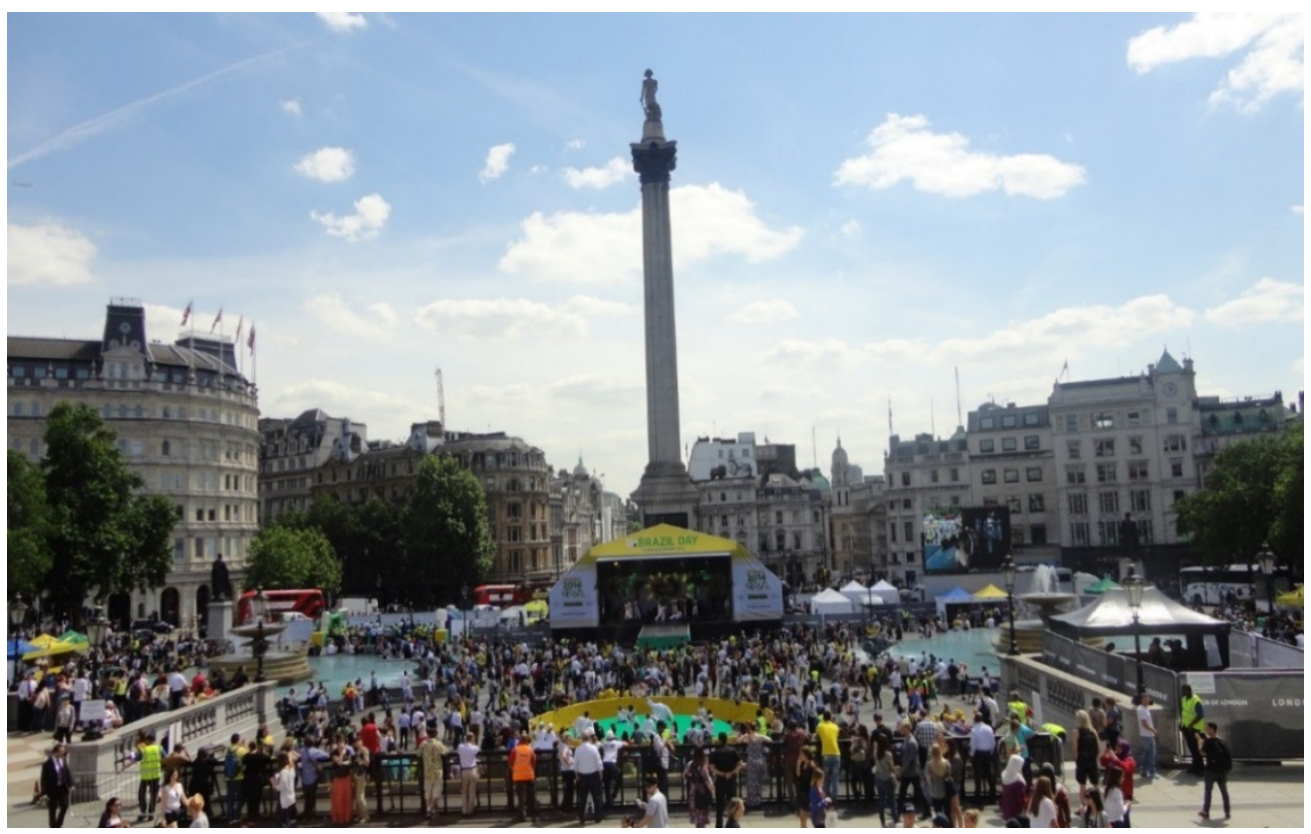

Fonte: BATARCE, A.P.A. 2014.

O último local de aplicação dos questionários face to face ocorreu durante as comemorações promovidas pela Capelania Católica brasileira. As festas juninas são um dos pontos de encontro da comunidade brasileira, um evento social que acontece nos locais em que a Capelania atende à comunidade brasileira: Willesden, Whitechapel, Manor House, Bayswater Brixton e Crystal Palace. Neste ano (2014) as comunidades de Brixton e Crystal Palace uniram-se para a realização deste evento, por onde passaram mais de 900 pessoas, segundo o capelão. Observa-se, na fotografia 4, o movimento no salão social da igreja católica de Crystal Palace.

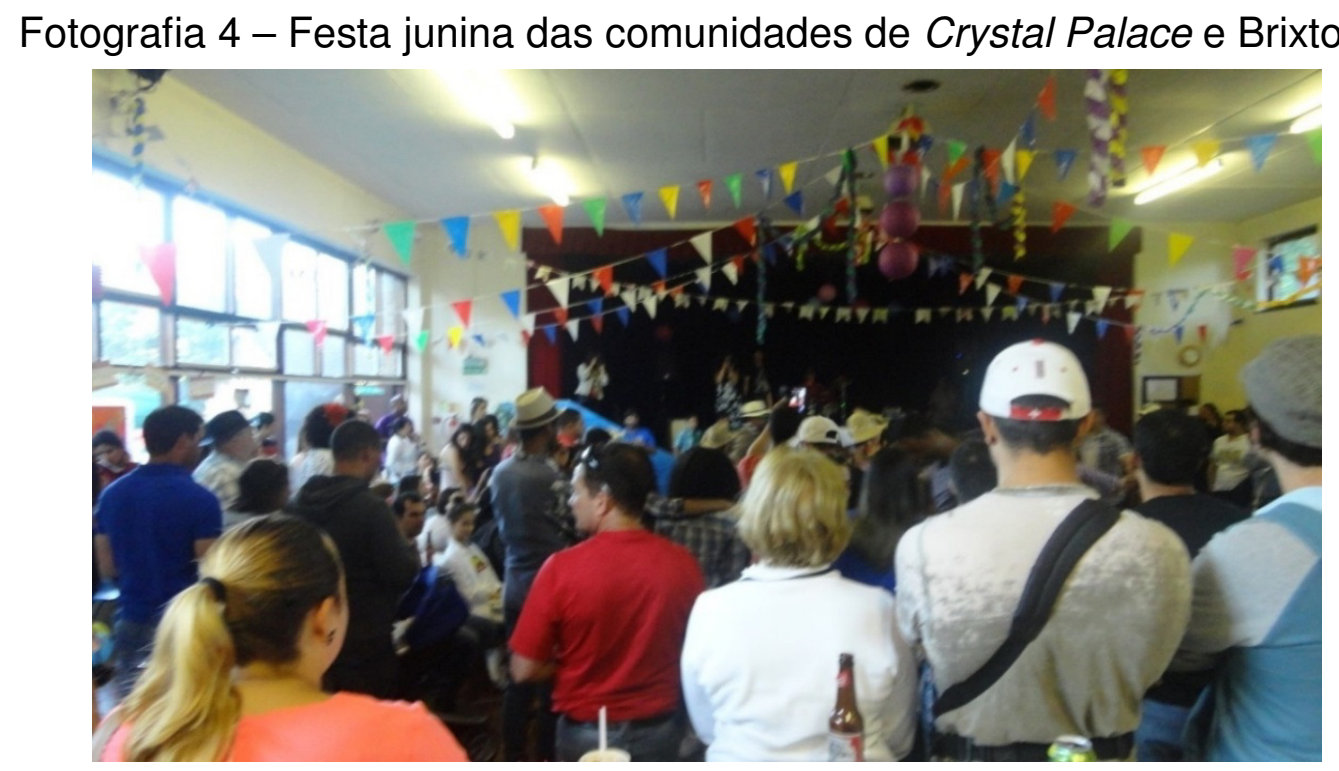

Fonte: BATARCE, A.P.A. 2014.

Estudos Geográficos, Rio Claro, 15(1): 210-230, jan./jun. 2017 (ISSN 1678—698X) http://www.periodicos.rc.biblioteca.unesp.br/index.php/estgeo 
A aplicação de questionários em lugares festivos não foi fácil, porque neles as pessoas querem diversão, querem conversar umas com as outras, portanto, não tendem a estar propícias a responder questionários. Foram ouvidos muitos "nãos" mas, mesmo assim, alguns "sins" apareceram. Um total de 20 mulheres concordaram em responder ao questionário durante as comemorações juninas.

No que se refere à aplicação indireta, foram considerados os questionários que foram deixados na Casa do Brasil e na LAWRS, duas organizações não governamentais. Em cada um destes lugares ficaram quinze cópias dos questionários, sob a responsabilidade, respectivamente, da secretária da Casa do Brasil e de uma brasileira que trabalhava na LAWRS e atendia mulheres que sofriam violência doméstica. Elas disponibilizaram os questionários para as mulheres brasileiras que se utilizavam dos serviços das referidas organizações. As cópias foram recolhidas e transferidas para o sistema estatístico online Survey Monkey.

A aplicação dos questionários no formato "online", também considerado como forma indireta de aplicação, ocorreu de duas formas. A primeira delas utilizou-se de contatos pré-existentes, tanto os estabelecidos no passado, antes da realização da pesquisa, quanto os contatos que foram estabelecidos no Consulado, no ano de 2014. Isso porque muitas das participantes preferiam preencher o questionário online; nestes casos, enviou-se o link gerado pelo Survey Monkkey para elas responderem. Ressalta-se que todas as mulheres que responderam ao questionário via e-mail foram contatadas pessoalmente e previamente. A partir desse recurso, resultaram 34 questionários.

Uma das redes sociais utilizadas na atualidade, o facebook, foi outra forma online de aplicação dos questionários. O convite para a participação na pesquisa foi lançado na página do GEB, na página dos "Brasileiros em Londres" e no grupo secreto do facebook, "Brasileiras em Londres". Apenas na página das "Brasileiras em Londres" os resultados foram positivos, pois foram respondidos 75 questionários. Esse grupo secreto foi uma indicação de uma das participantes da pesquisa.

As mulheres pertencentes ao grupo "Brasileiras em Londres" utilizavam o "facebook" para tirarem dúvidas sobre qualquer assunto, muitas, inclusive, referentes à migração. Elas marcavam e divulgavam encontros sociais, divulgavam informações de eventos brasileiros, de eventos ingleses interessantes para mães e crianças relativos a ensino de português, a compra e venda de objetos novos e usados, normalmente para crianças; ofereciam cursos para crianças brasileiras, sobretudo, cursos de português. Constatou-se que se tratava de um grupo formado por mais de 1000 mulheres brasileiras, que se socializavam virtualmente.

Em relação à criação do questionário, estatisticamente utilizou-se o sistema Survey Monkey, e isso tornou a coleta de dados flexível, pois pôde-se adquirir as respostas "cara a cara", como também enviar, por exemplo, convites via e-mail, ou via "Facebook", para que as mulheres respondessem "online". Assim, a possibilidade de acesso ao questionário virtualmente deu maior fluidez à pesquisa. Apesar de, no início, o programa parecer um tanto quanto rígido, justamente por ser um programa estatístico, sem muita maleabilidade, ele obrigou a pesquisadora a pensar muito bem e definir exatamente o que queria nas perguntas e respostas que foram direcionadas, uma vez que se tratava de um programa quantitativo de coleta de dados.

Outro aspecto de fluidez que o programa ofereceu foi o acesso online no exato momento da aplicação do questionário. Ou seja, o acesso à internet no local em que se realizava o questionário, permitiria que as respostas entrassem

Estudos Geográficos, Rio Claro, 15(1): 210-230, jan./jun. 2017 (ISSN 1678-698X)

http://www.periodicos.rc.biblioteca.unesp.br/index.php/estgeo 
automaticamente no sistema. Havia a intenção de se utilizar este formato na pesquisa, porém, no Consulado Brasileiro, não foi autorizado o uso da internet. Dessa forma, apesar de o sistema dar essa possibilidade e fluidez à pesquisa quantitativa, a opção de aplicação no formato impresso (papel) foi a mais segura e viável. Portanto, as respostas tiveram que ser lançadas no sistema posteriormente.

Mesmo assim, a utilização do programa foi vantajosa, pois ele forneceu as respostas tabuladas, com gráficos em diferentes formatos que foram exportados em PNG, PDF, PPT, CSV e principalmente no formato XLS - Excel.

Chama-se a atenção para a decisão de finalização da amostragem quantitativa. Em qual momento definiu-se finalizar a amostragem? No momento em que as respostas tornaram-se repetitivas e em que a quantidade adquirida já era satisfatória, permitindo que se identificasse o perfil geral das mulheres trabalhadoras brasileiras em Londres.

\section{PERFIL DO TRABALHO REALIZADO POR BRASILEIRAS EM LONDRES}

Os setores laborais ${ }^{3}$ declarados na amostragem pelas brasileiras são evidenciados nos gráficos ${ }^{4} 2,3$ e 4 . O grupo com maior representatividade (50 mulheres) está relacionado aos trabalhos realizados no setor de hotel/bar/restaurante. Em seguida, destaca-se o setor de negócios/administração com 38 mulheres e também o setor de limpeza com 30 mulheres. Não se pode deixar de mencionar o setor da saúde com 13 participações, o setor da educação com a participação de 12 mulheres e o setor do comércio com 11 mulheres.

Esses setores representam a economia formal, caracterizada pelo estabelecimento de contrato de trabalho e pelos direitos legais oferecidos às trabalhadoras. No entanto, outros atividades representadas, por exemplo, por diarista, "baby-sitter", "nanny", cuidadora de idosos e por outros tipos de serviços que podem ser esporádicos ou temporários são considerados informais. Além de não possuírem nenhum tipo de contrato formal, as pessoas inseridas nesses setores também não contribuem com os impostos. Já as mulheres que se declararam como profissionais liberais ou como autônomas contribuem com o pagamento de impostos.

Ressalta-se que, para cada setor evidenciado nos gráficos 2,3 e 4, demonstram-se: os trabalhos declarados que se relacionavam com a atividade laboral exercida pela mulher, mas que nem sempre eram formalizados; e os trabalhos registrados, que se relacionavam com a atividade laboral que as mulheres estavam exercendo e que realmente se tratava de um trabalho com contrato, ou seja, formalizado.

Percebe-se claramente essa situação no setor de limpeza (Gráfico 2), no qual 48 mulheres declararam realizar esse tipo de serviço, no entanto, apenas 18 possuíam contrato de trabalho; no caso das atividades em bares, restaurantes e cafés (Gráfico 3), das 47 mulheres que declararam realizar a atividade, apenas 30 tinha contrato de trabalho; no setor de saúde (Gráfico 4) percebe-se que a maioria das mulheres que declararam realizar o serviço possuíam o registro de trabalho.

\footnotetext{
${ }^{3}$ A divisão dos setores laborais utilizados na pesquisa empírica pautou-se nos trabalhos realizados por Evans com a comunidade brasileira em Londres (2010 e 2011).

${ }^{4}$ Estes gráficos foram estratificados com o objetivo de melhor visualização e compreensão da participação das mulheres nos diferentes setores laborais.

Estudos Geográficos, Rio Claro, 15(1): 210-230, jan./jun. 2017 (ISSN 1678-698X)

http://www.periodicos.rc.biblioteca.unesp.br/index.php/estgeo
} 
A dinâmica do trabalho de brasileiras em Londres...

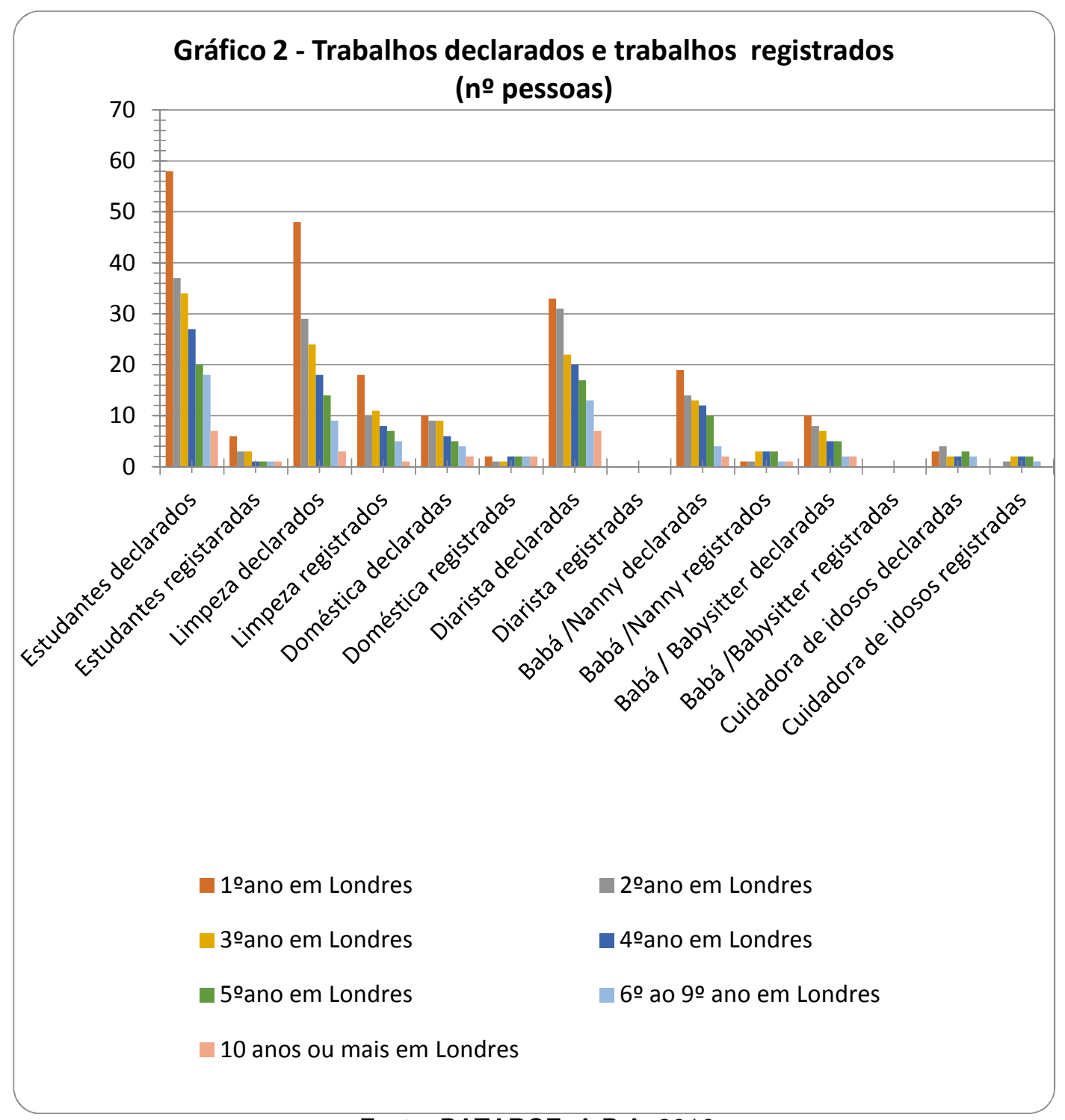

Fonte: BATARCE, A.P.A. 2016.

Estudos Geográficos, Rio Claro, 15(1): 210-230, jan./jun. 2017 (ISSN 1678-698X) 
A dinâmica do trabalho de brasileiras em Londres...

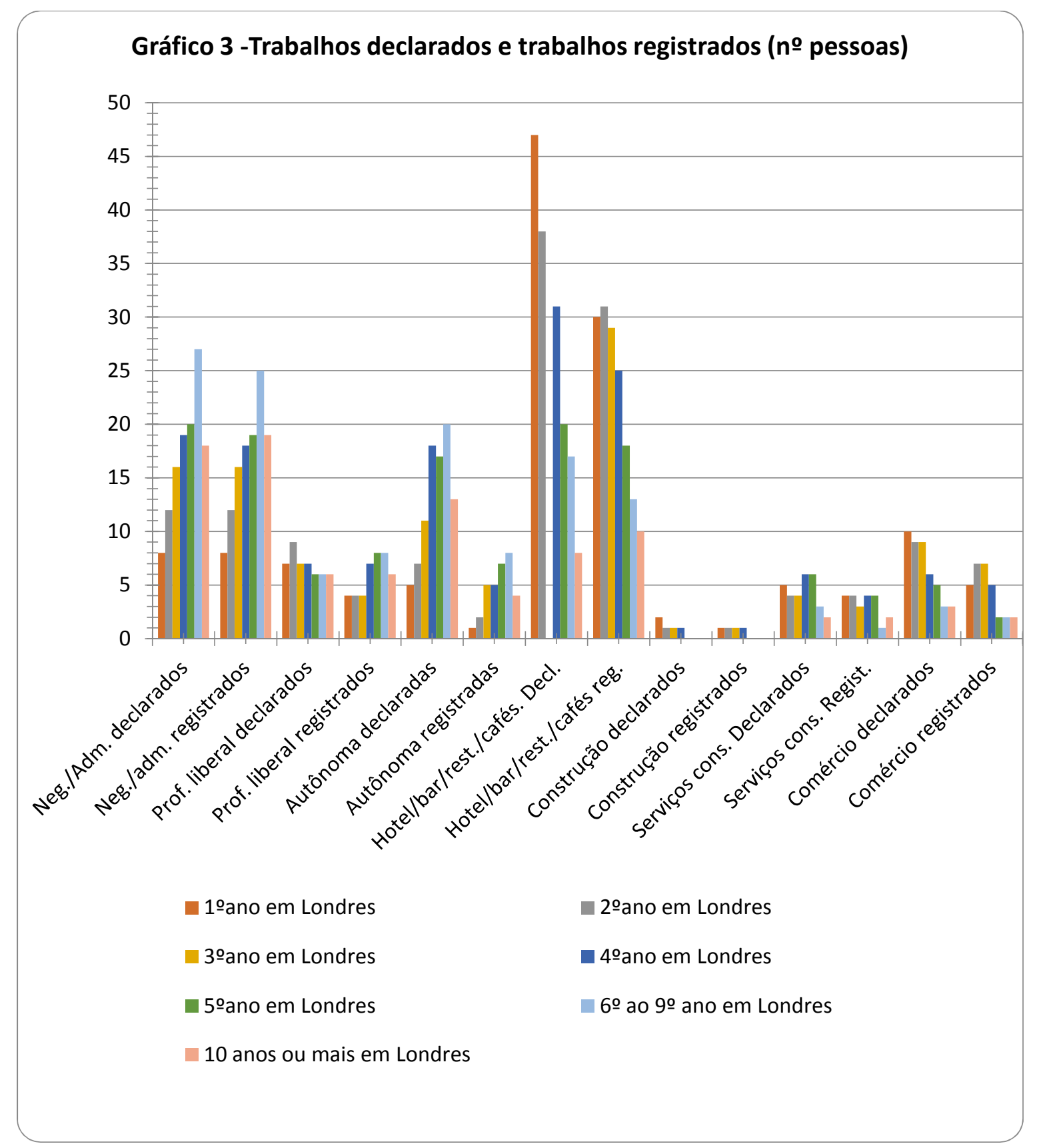

Fonte: BATARCE, A.P.A. 2016.

Estudos Geográficos, Rio Claro, 15(1): 210-230, jan./jun. 2017 (ISSN 1678-698X) 


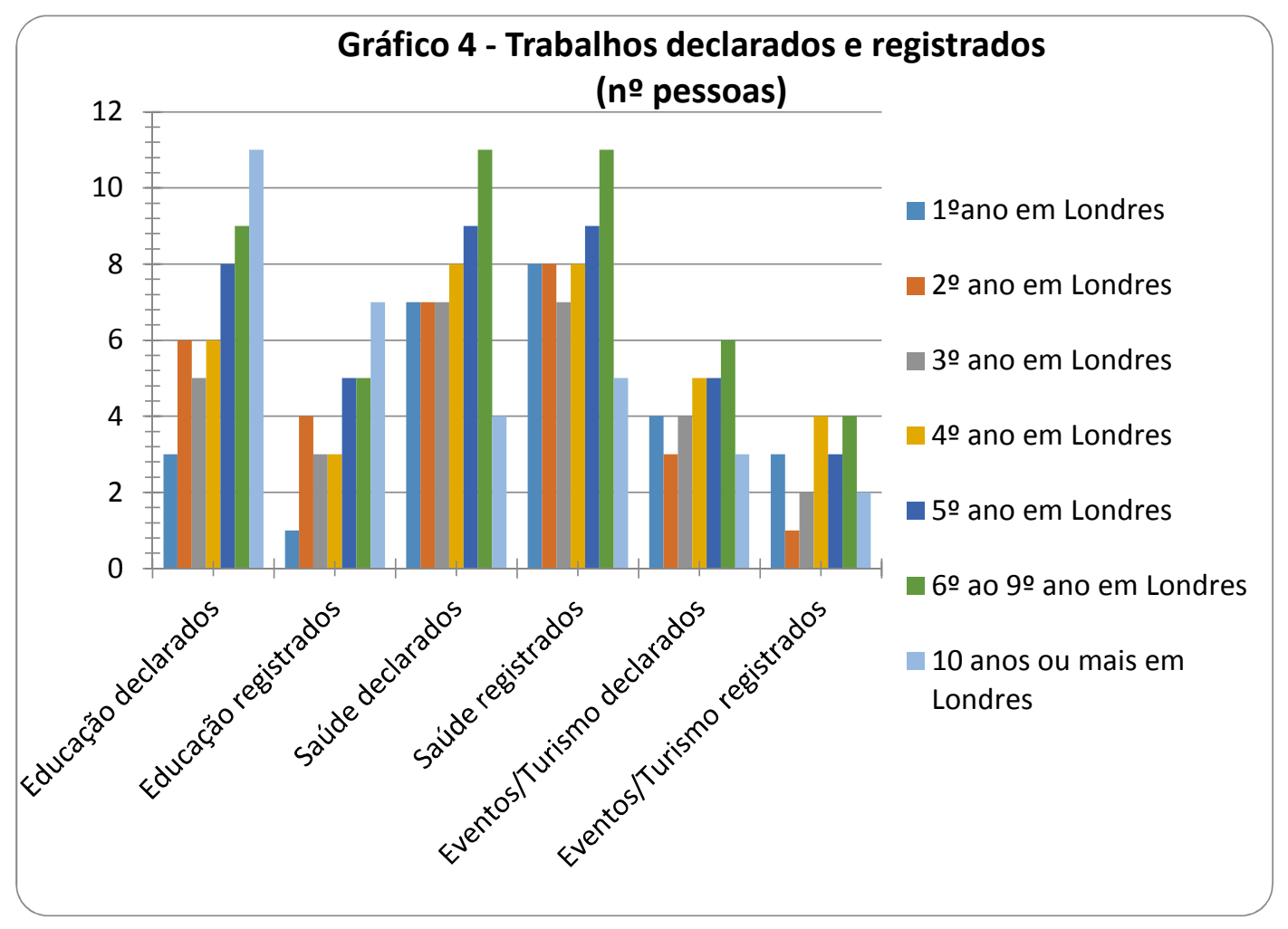

Fonte: BATARCE, A.P.A. 2016.

Verifica-se nos Gráficos 2, 3 e 4 que existem, nos diferentes setores laborais, trabalhos que eram realizados pelas mulheres brasileiras sem contrato de trabalho, de maneira informal.

No Gráfico 5, identificam-se seis setores laborais que demonstram ter havido, nos primeiros anos, a intensa participação das mulheres que, com o passar dos anos de residência em Londres, sofreu decréscimo, a exemplo do de estudantes ${ }^{5}$, que representa 58 pessoas no primeiro ano de residência em Londres. Percebeu-se que essa atividade vai decaindo com o passar dos anos, chegando à categoria dez anos ou mais com apenas 8 mulheres, que continuam estudando. Segundo as entrevistas realizadas posteriormente à realização da pesquisa quantitativa, algumas dessas mulheres salientaram que ter o visto de estudante era a única forma de elas se manterem legais na Inglaterra.

As mulheres que no início realizavam atividades em hotel/bar/restaurante representam um total de 53 pessoas que, com o passar dos anos, deixam de realizar tal atividade, assim a participação reduz para 8 pessoas. A realização de serviço de limpeza em escritórios, pubs e hospitais foi representada por 48 pessoas no primeiro ano de sua residência em Londres; no momento da pesquisa, apenas 8 trabalhadoras estavam realizando a atividade e residiam há dez anos ou mais anos em Londres.

Entre as atividades apresentadas no Gráfico 5, as que têm maior reconhecimento financeiro são as de baby-sitters e as nannys. No primeiro ano de residência em Londres, eram atividades realizadas de maneira informal, pois muitas famílias inglesas necessitavam de pessoas para cuidar de seus filhos e muitas

\footnotetext{
${ }^{5}$ Considera-se nesta pesquisa a estudante como uma categoria laboral, pois se trata da realização de trabalho intelectual.

Estudos Geográficos, Rio Claro, 15(1): 210-230, jan./jun. 2017 (ISSN 1678—698X)

http://www.periodicos.rc.biblioteca.unesp.br/index.php/estgeo
} 
mulheres brasileiras, por necessitarem trabalhar, aceitavam realizar a atividade: era fácil e rápido conseguir esse tipo de emprego. Essas atividades também sofreram queda em sua realização com o passar dos anos.

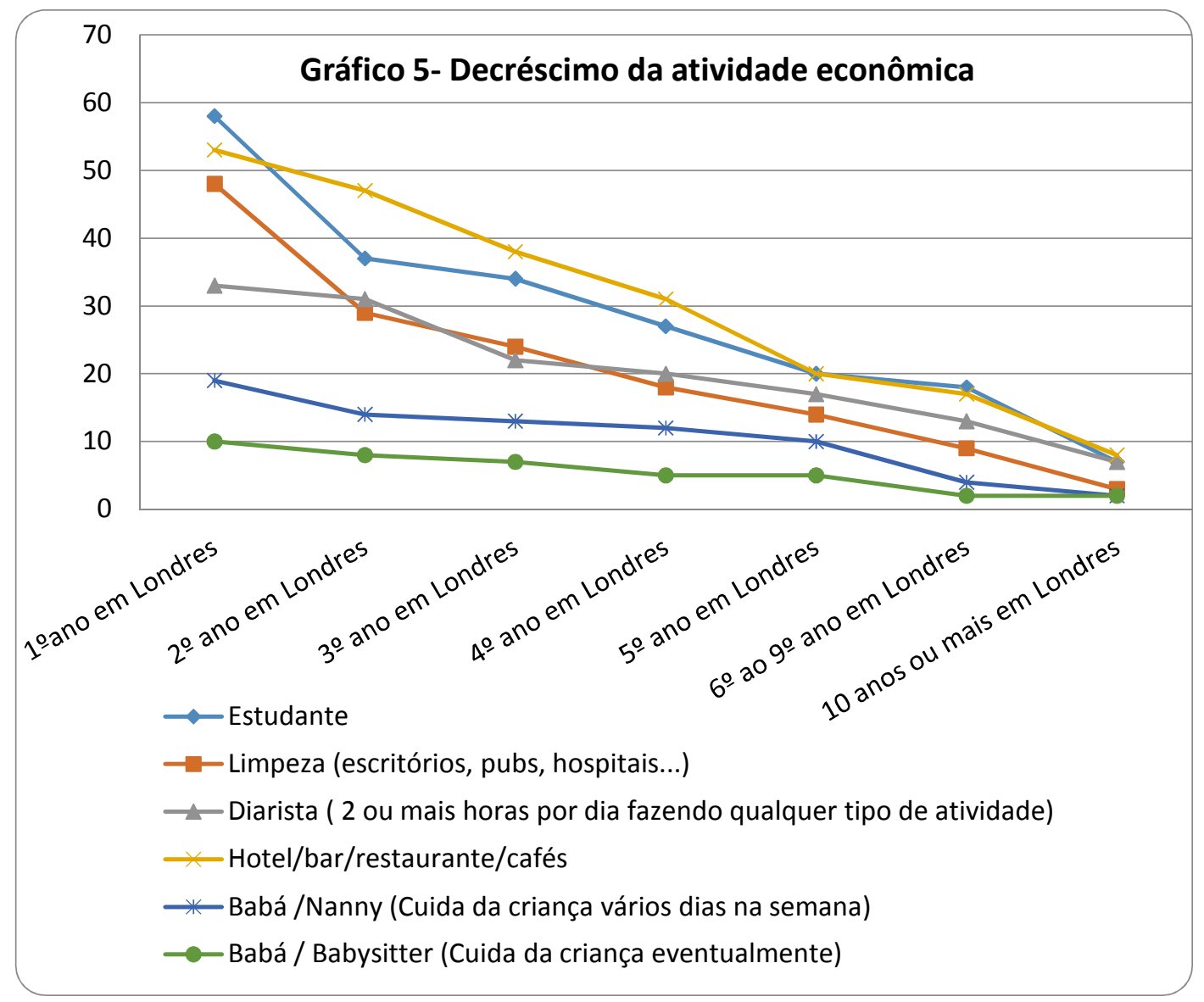

Fonte: BATARCE, A.P.A. 2016.

O Gráfico 6 apresenta as principais atividades econômicas declaradas na pesquisa. A atividade de maior crescimento é a relativa à categoria negócios/administração e diz respeito até o quinto ano de residência em Londres; no entanto, depois do $6^{\circ}$ ao $9^{\circ}$ ano sofre queda. Importante destacar que várias das participantes autônomas consideravam-se nessa categoria, por possuírem o próprio negócio. Percebeu-se que a categoria autônoma apresentou crescimento do $6^{\circ}$ ao $9^{\circ}$ ano e depois sofreu queda. A atividade no setor da saúde também apresentou crescimento do $6^{\circ}$ ao $9^{\circ}$ ano e depois sofreu queda. A única atividade laboral que cresceu, desde o primeiro ano até o décimo ano ou mais de residência em Londres, foi o setor relacionado à educação.

Estudos Geográficos, Rio Claro, 15(1): 210-230, jan./jun. 2017 (ISSN 1678—698X) 
A dinâmica do trabalho de brasileiras em Londres...

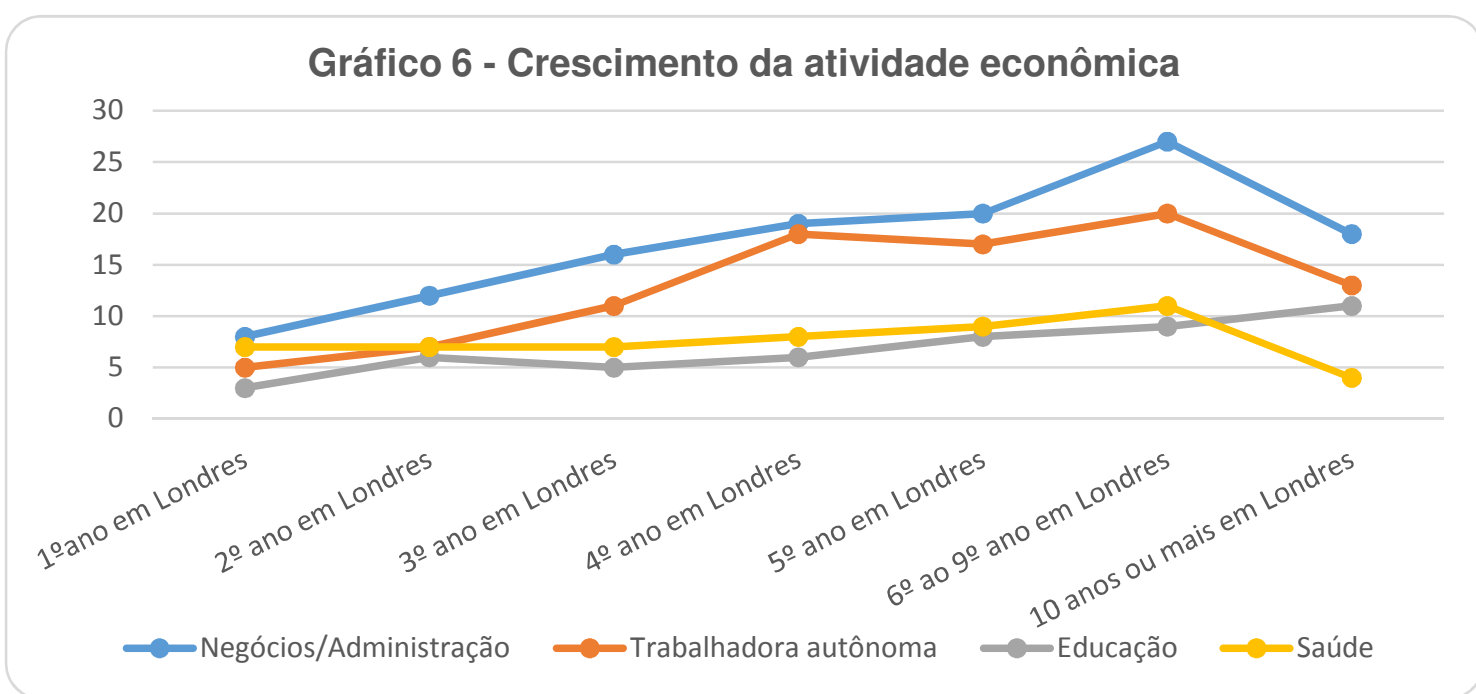

Fonte: BATARCE, A.P.A. 2016.

Em relação à variação salarial apresentada na pesquisa, o Gráfico 7 conduz às informações das participantes nos diferentes anos de trabalho e residência em Londres. Faz-se necessário deixar claro que a política salarial inglesa se baseia em horas trabalhadas, ou seja, a pessoa recebe o salário pelas horas que trabalha durante o dia, durante o mês, durante o ano. Sendo assim, o valor mínimo por hora de trabalho em 2014 era de $£ 6,50$.

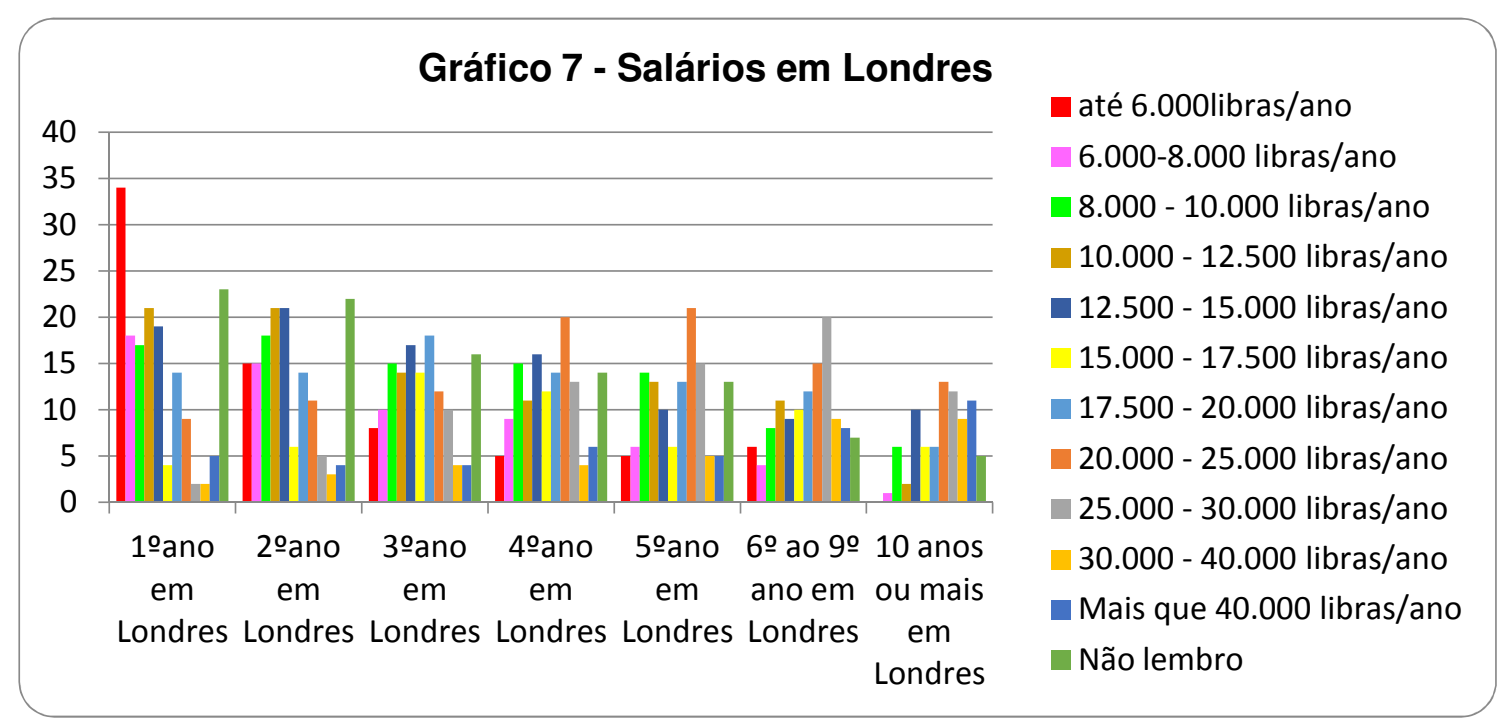

Fonte: BATARCE, A.P.A. 2016

A primeira faixa salarial de 6000 libras refere-se ao salário total de uma pessoa durante um ano de trabalho na cidade de Londres. Nesta situação salarial encontraram-se 34 mulheres no primeiro ano; 15 mulheres no segundo; 8 mulheres no terceiro; 5 mulheres no quarto; 5 mulheres no quinto; 5 mulheres receberam 6000 libras do sexto ao nono ano. Nenhuma mulher com dez anos ou mais de residência em Londres recebeu até 6000 libras por ano.

Estudos Geográficos, Rio Claro, 15(1): 210-230, jan./jun. 2017 (ISSN 1678—698X)

http://www.periodicos.rc.biblioteca.unesp.br/index.php/estgeo 
$\mathrm{Na}$ segunda faixa salarial, de 6000-8000 libras, que se refere ao salário total de um ano de trabalho, encontraram-se 18 mulheres no primeiro ano; 15 mulheres no segundo; 10 mulheres no terceiro; 9 mulheres no quarto; 6 mulheres no quinto. Do sexto ao nono ano encontraram-se 4 mulheres e acima de dez anos encontrouse 1 mulher.

Observa-se, no Gráfico 7, que a participação na faixa salarial que vai de 8000 libras/ano até a faixa de 15.000 libras/ano é bem representativa desde o primeiro ano de residência. Já a faixa de 15.000 libras/ano -17.500 libras/ano não tem muita representatividade no primeiro e segundo anos de residência em Londres tornandose mais expressiva a partir do terceiro ano.

A representatividade diminui nas faixas que vão de 17.500 libras/ano a 20.000-25.000 libras/ano, a partir do primeiro ano de residência, diminuindo mais ainda, a partir dos ganhos acima de 25.000 libras/ano, nos primeiros anos de estabelecimento econômico dessas pessoas naquela cidade. $\mathrm{O}$ gráfico 7 demonstra que, apenas no quarto e no quinto anos de residência em Londres, a pessoa consegue galgar essa faixa salarial.

Representa-se no gráfico 7 a variação salarial das mulheres que participaram da pesquisa. Salienta-se que a mesma mulher que declarou ganhar 6000 libras no primeiro ano de trabalho em Londres poderá estar representada no quinto ano com o salário de 20.000 libras/ano, como também esta mesma mulher no quinto ano poderá ter uma faixa salarial de 12000 libras/ano. A definição da faixa salarial é individual e depende do caminho que essa mulher seguiu durante os anos, por exemplo, existiram mulheres na pesquisa que chegaram em Londres, começaram a trabalhar, pararam de trabalhar por um tempo, depois voltaram a trabalhar novamente. Muitas vezes, ao voltarem a trabalhar, passam a exercer uma atividade econômica completamente diferente, tudo isso acaba atingindo a variação salarial. É claro que existe a relação de que quanto mais tempo residindo e exercendo uma atividade econômica, melhores salários poderão ser conquistados, mas nem sempre se pode utilizar esta relação para todas as pessoas. Assim se representa, no Gráfico 7, parte da realidade de tais mulheres.

Segundo a faixa salarial apresentada para o ano de 2014, destacaram-se, no Gráfico 8, os valores relacionados às faixas de 12.500-15000 libras, 25.000-30.000 libras e 30.000-40.000 libras. Ao se agrupar a primeira e a segunda faixas salariais tem-se, aproximadamente, uma representação de 12,7\%. Essas mulheres provavelmente são mães e por isso trabalham poucas horas diárias, ou são mulheres que ainda não se estruturaram economicamente em Londres, ou ainda são estudantes que trabalham poucas horas semanais apenas para se manter e assim não ter que atrapalhar os estudos. 
A dinâmica do trabalho de brasileiras em Londres...

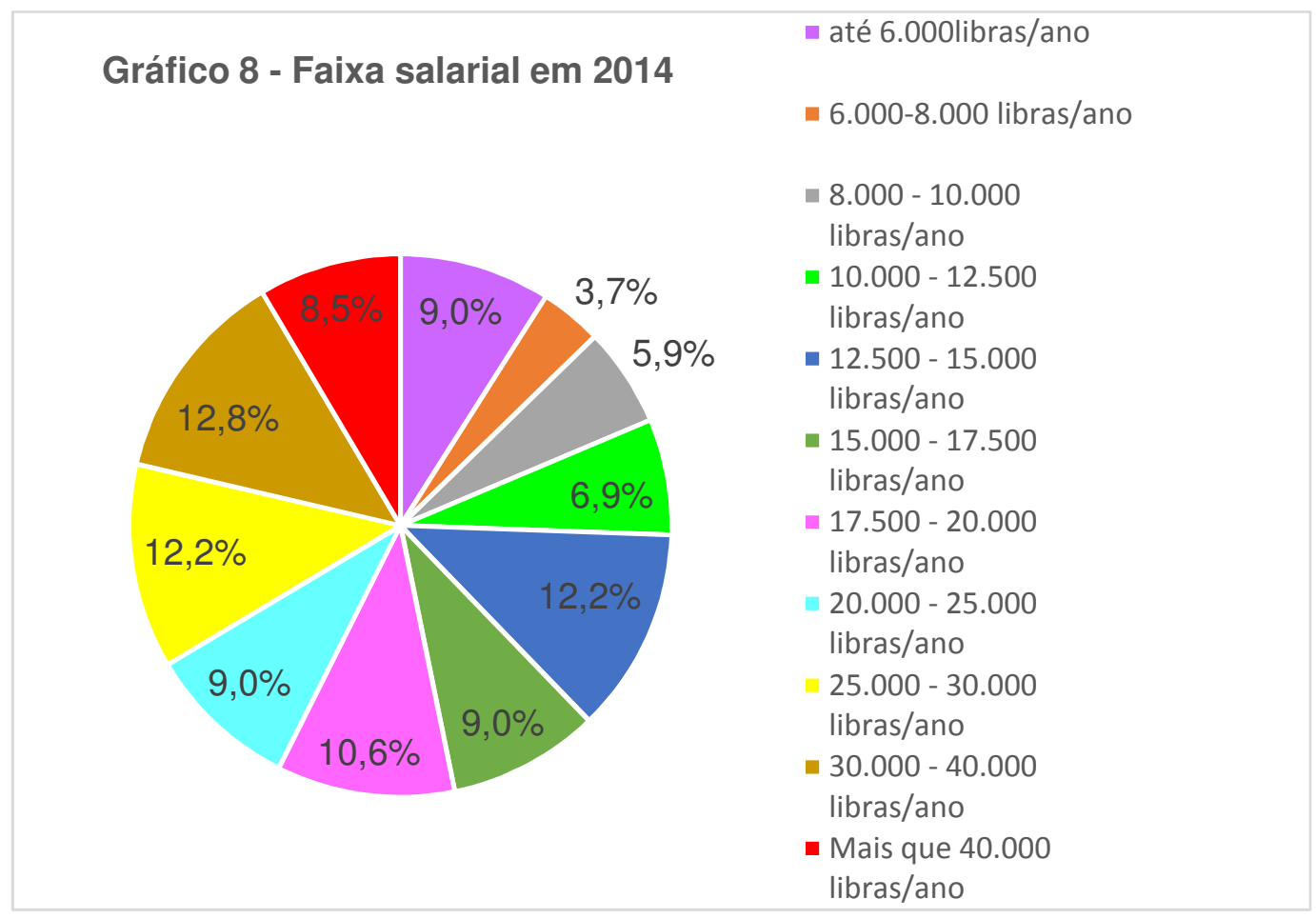

Fonte: BATARCE, A.P.A., 2016.

Observa-se, no Gráfico 9, que 99,5\% das mulheres possuem um emprego; $20,2 \%$ destas responderam que trabalham em dois lugares diferentes diariamente; $5,9 \%$ trabalham em três lugares diariamente e 1,6\% declararam trabalhar em 4 lugares diferentes diariamente.

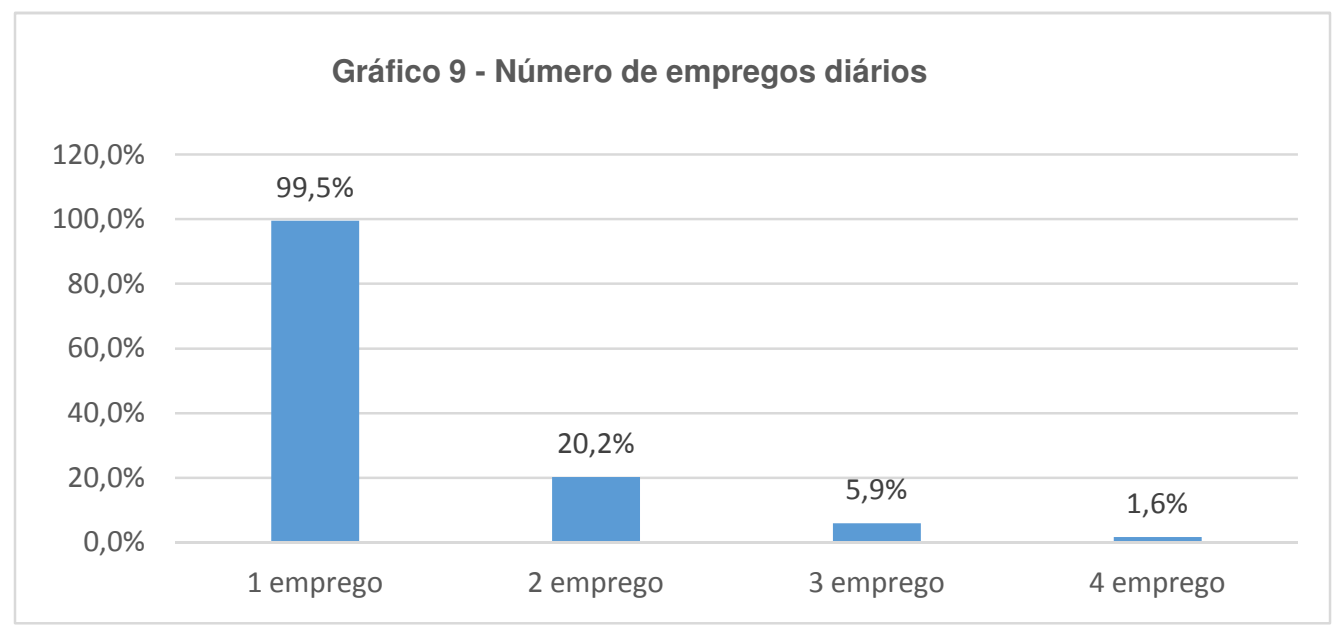

Fonte: BATARCE, A.P.A., 2016.

Destaca-se que a maioria das mulheres que possuem dois a quatro empregos diários realiza a segunda, a terceira ou a quarta atividade no setor de limpeza. Muitas declararam que possuíam até três casas por dia, outras que possuíam até quatro casas por dia. Em ambas as situações, as residências em que realizavam a atividade de limpeza eram próximas umas das outras, caso contrário não conseguiriam trabalhar em todas as casas no mesmo dia.

Estudos Geográficos, Rio Claro, 15(1): 210-230, jan./jun. 2017 (ISSN 1678—698X) http://www.periodicos.rc.biblioteca.unesp.br/index.php/estgeo 
A outra situação relaciona-se à limpeza em escritórios, pubs e restaurantes. Este tipo de limpeza ocorre normalmente antes do início das atividades diárias. A pessoa responsável pela limpeza inicia o trabalho por volta das 5 ou 6 horas da manhã e termina, no máximo, até às 9 da manhã. Ou então, realiza a limpeza no final do expediente, quando são encerradas as atividades do local. Situação comum em escritórios, cuja limpeza ocorre após as 18 horas; o prazo de término compreende duas, três ou quatro horas, tudo depende do tamanho do escritório.

Demonstra-se, no Gráfico 10, que as mulheres que possuem um emprego o mantêm por alguns anos, o mesmo ocorrendo com as mulheres que possuem dois empregos diários.

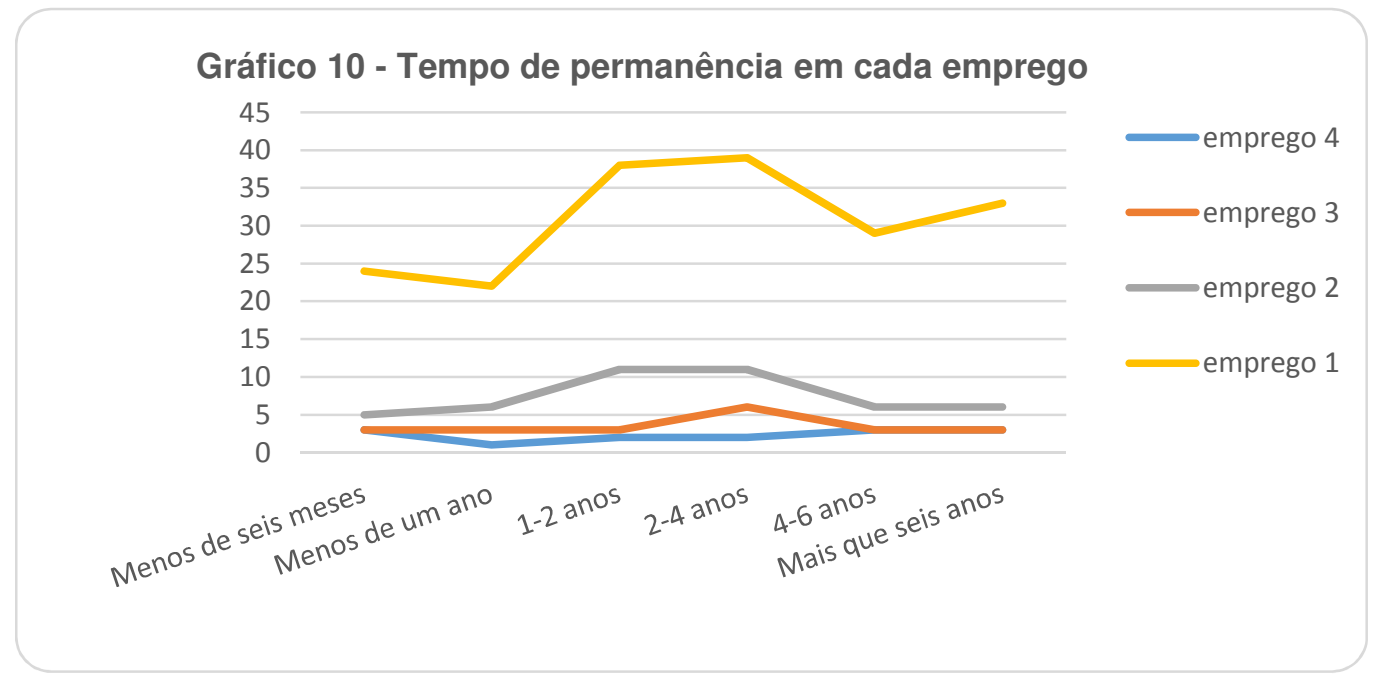

Fonte: BATARCE, A.P.A., 2016.

No que diz respeito ao número de horas trabalhadas por dia, percebe-se, no Gráfico 11, que as mulheres que têm apenas um emprego trabalham majoritariamente de 4 a 10 horas por dia. As mulheres que têm dois empregos trabalham, normalmente, um maior número de horas no principal emprego (de 5 a 8 horas) e um menor número no emprego secundário (de 2 a 4 horas). No entanto, aquelas que trabalham no setor de limpeza podem ter uma variação de duas a 5 horas em cada casa, ou em cada local em que realizam a atividade.

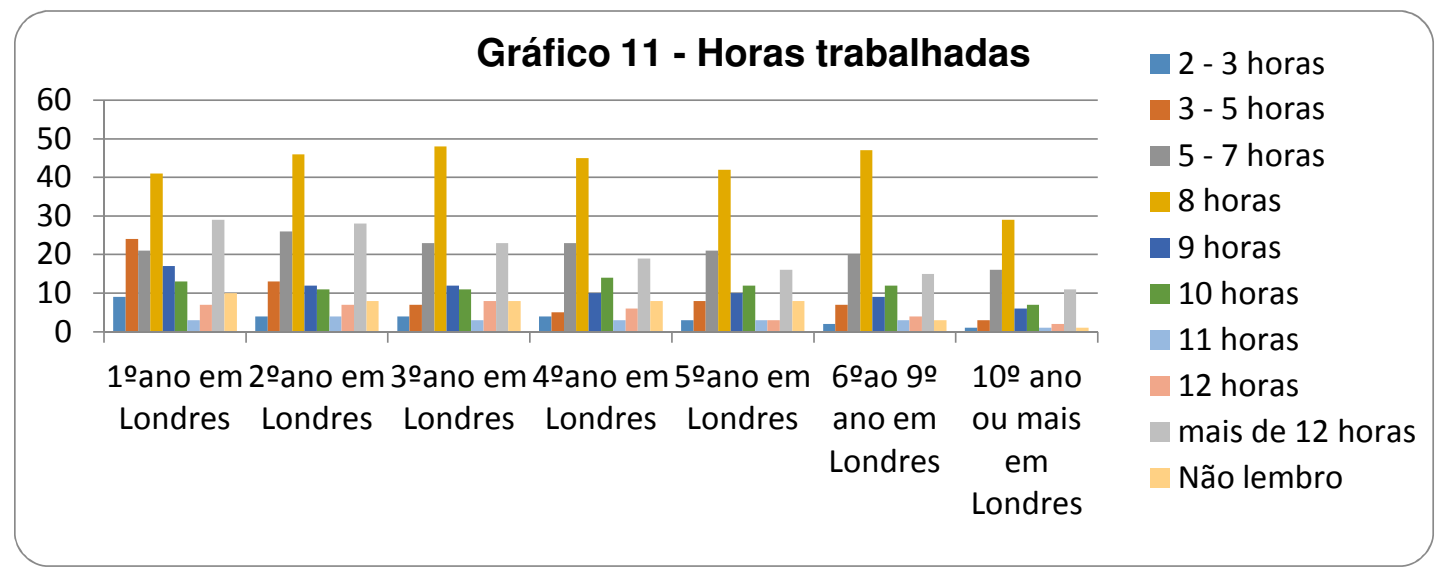

Fonte: BATARCE, A.P.A., 2016.

Estudos Geográficos, Rio Claro, 15(1): 210-230, jan./jun. 2017 (ISSN 1678—698X) 


\section{CONSIDERAÇÕES FINAIS}

Pesquisar o movimento migratório internacional de mulheres brasileiras para Londres possibilitou conhecer um pouco mais sobre essa realidade, sobre como se articula a atividade laboral de uma parcela de mulheres migrantes brasileiras, sobre como o trabalho realizado por essas mulheres se materializa em outro território, outra cultura, como a da capital inglesa, cidade cosmopolita que ocupa a primeira colocação entre os principais centros financeiros do mundo.

Mais uma vez, frisa-se a relevância do delineamento metodológico exposto anteriormente, sobretudo sobre o detalhamento do planejamento analítico da pesquisadora na elaboração da pesquisa empírica (pesquisa quantitativa e qualitativa) que proporcionou, a partir do questionário, a aquisição dos dados necessários para traçar o perfil das trabalhadoras brasileiras que se encontravam em Londres, no ano de 2014.

Os dados apontaram que, nos primeiros anos de trabalho em Londres, as mulheres da amostragem, ou realizavam atividades no setor de limpeza, no de bares, restaurantes, pubs, hotéis, ou exerciam funções como a de "baby-sitter" ou a de "nanny". Muitas delas, ao mesmo tempo em que trabalhavam, também eram estudantes. Percebeu-se que, com o passar dos anos de residência e trabalho em Londres, o salário que, no início era de 6000 libras/ano, cresceu atingindo patamares mais elevados. Ressalta-se que esse crescimento salarial está conectado com 0 status migratório. Se a mulher estivesse indocumentada dificilmente alcançaria salários mais elevados, no entanto, se ela estivesse documentada as chances de ganhar melhores salários eram possíveis, o que se comprovou com a pesquisa.

Evidenciou-se também que as mulheres, em sua maioria, trabalhavam de 8 a 10 horas diárias. Existiram aquelas que possuíam mais de um emprego, portanto, trabalhavam mais horas por dia. Existiam aquelas que realizavam apenas poucas horas de trabalho semanal, por exemplo, uma mulher que estudava a semana toda, trabalhava apenas nos finais de semana, ou uma mulher que possuía criança pequena também trabalhava poucas horas semanais.

No momento de realização da pesquisa, as mulheres brasileiras possuíam faixa salarial em Londres relativamente variada entre 6.000 a 40.000 libras dependendo da condição migratória de cada uma e da quantidade de horas trabalhadas. Percebeu-se, ainda, que a as mulheres não trocavam muito de emprego, então a mobilidade laboral não se apresentou de forma intensa como se pensava em espaços de forte imigração.

As informações adquiridas na pesquisa empírica foram de fundamental importância, pois permitiram melhor compreensão da migração internacional de brasileiras para Londres e as inter-relações que aconteceram na atividade laboral. 


\section{REFERÊNCIAS}

BANCO MUNDIAL. Population total. Disponível em $<$ http://data.worldbank.org/indicator/SP.POP.TOTL>. Acesso em: 07/07/2017.

BATARCE, A. P. A. Imigração brasileira para o Reino Unido: 0 trabalho das mulheres em Londres e os processos de identificação/diferenciação. 2016. 292 f. Tese (Doutorado em Geografia) - Universidade Estadual Paulista - UNESP, Rio Claro, 2016.

EVANS, Y. et al. Por uma vida melhor: brasileiras e brasileiros em Londres, 2010. GEB (Grupo de Estudos sobre Brasileiros em Londres) Londres, Reino Unido, março de 2011.

EVANS, Y. Brasileiros em Londres: um perfil socioeconômico. Travessia: Revista do Migrante, São Paulo, n., p.9-20, jan. 2010.

MINISTÉRIO DAS RELAÇÕES EXTERIORES (MRE). 2009. Brazilian in the World: estimates 2008, 2009, 2011, 2012 and 2014. Brasília: Ministério das Relações Exteriores. Disponível em: <http://www.brasileirosnomundo.itamaraty.gov.br/acomunidade/estimativas-populacionais-das-comunidades $>$.

Acesso em: 10/07/2015

2015. Brasileiros no Mundo:

estimativas populacionais das comunidades brasileiras no Mundo - 2015.

Brasília: Ministério das Relações Exteriores. Disponível em:

http://www.brasileirosnomundo.itamaraty.gov.br/a-comunidade/estimativaspopulacionais-das-comunidades/Estimativas\%20RCN\%202015\%20-

\%20Atualizado.pdf

Acesso em: 07/07/2017

OLIVEIRA, A. C. Japoneses no Brasil ou Brasileiros no Japão: A trajetória de uma identidade em um contexto migratório. 1997. 207 f. Dissertação (mestrado) Departamento de Sociologia do Instituto de Filosofia e Ciências Humanas da Universidade Estadual de Campinas, Universidade Estadual de Campinas, Campinas, 1997.

ORGANIZAÇÃO DAS NAÇÕES UNIDAS (ONU). International migration flows to and from selected countries: The 2015 revision. Disponível em:

$<$ http://www.un.org/en/development/desa/population/migration/data/empirical2/migrat ionflows.shtml $\geq$

Acesso em: 07/07/2017.

VALENTINI, Luiz Demétrio. Apresentação. In: MIGRANTES, Serviço Pastoral Dos et al. Travessias na Desordem Global. Fórum Social das migrações. São Paulo: Paulinas, 2005. (Coleção mundo possível). 